\title{
Uzbek Migrants' Everyday Encounters with Police Officers and Immigration Officials
}

During my ethnographic fieldwork in Moscow (January 2014-August 2018), I frequently visited a construction site in Balashikha, a small city in Moscow province where dozens of Uzbek migrant construction teams performed various types of construction work in high-rise residential buildings. Because the construction of the residential buildings had already been completed, the primary task performed by these Uzbek construction teams entailed the final finishing and design work, such as window fitting, painting, flooring, wallpaper installation, plumbing, or electrical installation. Like many construction projects in Moscow, this Balashikha-based project was coordinated by a Russian intermediary who worked for a large construction company responsible for the overall project implementation. Because of language barriers and cultural differences, however, the Russian intermediary coordinated the construction project through several Uzbek migrant middlemen who were well-connected to migrant construction workers, enjoyed authority among them, knew their language, and could manage construction brigades. In turn, the migrant middlemen struck deals with various Uzbek construction teams (each consisting of 5-10 migrants), acting as an intermediary between different parties.

Nearly all of the Uzbek migrants I encountered there worked without any written employment contract and did not have an authentic residence registration or work permit. Migrants working there said that it was impossible to go "legal" (qonuniy yurish) in Balashikha, since they all, regardless of whether they were documented or not, had to pay a bribe to police officers. In the words of the migrants, Balashikha used to be a forbidden military zone during the Soviet times, where foreigners were not allowed to live or work, and this Soviet legacy was strategically used by police officers who always sought reasons to extort money from migrants. 
When stopped by the police, migrants were often warned that they were working in a forbidden zone and that they needed special permission from the Russian state-permission created to justify the police demands for bribes from migrants. The police typically demanded 2,000 rubles (US\$30) to ignore this "infraction," but migrants often managed to get away with paying 500 rubles (US $\$ 8$ ). When police officers approached the construction site, everyone hid. Migrants typically spent most of their time inside the apartments where they simultaneously worked and lived. Unless a Russian complained or a letter arrived from a prosecutor, the police did not enter and check the apartments.

Given their daily experiences with corruption, migrants developed multiple strategies to avoid the police. If they needed something from the market, they usually checked the area thoroughly to make sure no police officers were around. When they saw the police on the street, they quickly informed one another. But it was not always possible to avoid hungry police officers, who frequently wander around markets and bus stops. If a migrant was caught when buying food stuff for the construction brigade, all of the migrants shared the cost of the bribe paid to police, viewing it as part of their food expenses. Whenever I visited my key informants (migrant brigades) in Balashikha, they quickly brought up the subject of police corruption and talked openly about situations in which they had paid bribes to Russian police officers. Migrants often told different stories and anecdotes about police corruption. During my visit to Balashikha in April of 2014, I organized a small pilaf (a festive Uzbek rice) party for several migrant brigades as a way to socialize and establish a close relationship with them. We sat a nicely decorated table, eating pilaf and talking about the migrants' daily lives and adventures in Russia. Spontaneously, one of the migrants provided an anecdote about police corruption:

There was one Russian police officer who made his fortune extorting money from Uzbek migrants. He worked near construction sites, where many migrants lived and worked. Due to the existence of thousands of migrants in his territory, he generated lots of income and became very rich, to the extent that he managed to buy a villa in Rublevka, an elite residential area in the western suburbs of Moscow where many Russian billionaires live. This was an unexpected turn for the police officer, who was not actually a Muscovite, but from Siberia. He was very proud of his achievement and continued to extort money from migrants on a daily basis. However, one day his 12-year-old son, his only child, died in a car accident. This tragic event left the police officer deeply saddened. Because the police officer shared his revenues with many people in the government, many state officials showed up to his son's funeral. Even Sergey Sobyanin, the mayor of Moscow, attended his son's funeral to express his condolences. When the funeral was about to end, suddenly more than 100 Uzbek migrants arrived at the funeral, all of whom were sad and crying as if they had lost their own child. The police officer recognized many of the migrants as individuals from whom he had regularly extorted money. But, still, the policeman could not 
understand why so many migrants felt sorry for him and cried even though he had terrorized them on a daily basis. When the police officer asked the migrants why they had come to the funeral despite their bad experiences with him, one migrant replied, "Of course, we must be here. True, he is your son, not ours. But do not forget the fact that we raised him for many years, paying for his food, clothes, toys, and all of the other expenses related to his childhood. We invested more money in your son than you."

That last phrase was accompanied by loud laughter and nodding, showing the migrants' awareness of the widespread police corruption slyly hinted at in the anecdote. This anecdote indicates that police corruption has become something of a norm, whereby finding migrants who have not paid a bribe to Russian police officers remains difficult. The anecdote also clearly provides a clue regarding the existence of a plethora of interests and networks within the Russian government that benefit from informal transactions involving police officers and migrant workers. This anecdote thus begs the question of how migrant legal adaptation takes place within a legal environment characterized by corruption and lacking a rule of law. In this chapter I provide illustrations of this process by presenting substantial ethnographic data on migrants' everyday interactions with police officers and immigration officials.

\section{BECOMING “LEGAL” IN A CORRUPT AND \\ WEAK RULE-OF-LAW ENVIRONMENT}

As discussed in previous chapters, Russian immigration laws determining the conditions for the legal status of foreign citizens remain inconsistent, poorly enforced, and often contradictory (Kubal 2016a). This is unsurprising given that much of the academic literature describes the Russian legal environment as corrupt, arbitrary, and repressive (Sakwa 1995; Gel'man 2004; Solomon 2004; Ledeneva 2006). Thus, even those migrants who possess all of the required documents cannot be sure that they will not encounter problems when they come into contact with Russian police officers and immigration officials (Reeves 2015; Kubal 2016b). Given the weak rule of law, widespread corruption, and arbitrary law enforcement, being "legal" or "illegal" hinges on contextual factors and individual skills. These factors and skills include how, when, and where the interaction between migrants and Russian state officials takes place as well as migrants' knowledge of informal rules, street smarts, bribery skills, and ability to negotiate and find common ground (obshiy yazik) with state officials. These legal uncertainties imply the near impossibility of a migrant being fully documented, while the only path to asserting one's "legality" requires using various informal and illegal practices and procedures (Dave 2014a).

Much of the prevailing research tends to portray Central Asian migrants in Russia as passive, agencyless subjects. As such, they are constrained by the punitive 
legal environment, pointing out how being undocumented incapacitates migrants and invades their lifeworlds, leading to ever-present threats of exploitation, deportation, police corruption, racism, physical violence, and even death (Light 2010; Ruget and Usmanalieva 2010; Reeves 2015; Abashin 2016; Kubal 2016a; Round and Kuznetsova 2016; Agadjanian, Menjívar, and Zotova 2017; Nikiforova and Brednikova 2018; Schenk 2018). A similar perspective also commonly pervades the broader "migrant illegality" literature (based on research conducted in North America and Western Europe), where immigrants' legal status represents a key factor determining various paths, as well as the quality and timescale of migrant integration (Massey, Durand, and Malone 2002; Coutin 2003b; Calavita 2005; Menjívar 2006, Gleeson 2010). In other words documented and undocumented migrants have such varying experiences that they constitute two different social classes.

The treatment of migrants as passive, agencyless subjects, however, may preclude us from looking at their actual coping strategies and navigational skills. Take the example of Malaysia, as Garcés-Mascareñas (2010) shows, where undocumented migrants, unlike documented migrants, enjoy more opportunities to change jobs, can negotiate their salary and working conditions, can avoid extra fees to enter or remain in the country, and can extend their stay in the country regardless of their economic situation or health status. Garcés-Mascareñas (2010) suggests that illegality can be viewed as a form of everyday, hidden resistance to state migration control policies. In Russia, by comparison, migrants also face similar constraints where they must deal with the arbitrary and repressive legal environment that does not allow migrants to legalize their work and residence status. Even those migrants with perfectly "clean" documents cannot be certain that they are "legal" when stopped by police officers. In the Russian context, however, "illegality" does not automatically incapacitate migrants, confining them to the space of vulnerability and legal nonexistence. Rather, it becomes a way of life, something of a norm for millions of migrants in Russia. Consequently, when the state forbids things or makes it nearly impossible to follow official procedures, it creates the need for informal and illegal means of getting things done (Morris and Polese 2015b). This means that migrants are forced into informal relations with the state in their everyday life (Kuznetsova and Round 2018). As we have seen, these constraints force many migrants to operate in the shadow economy (Heusala and Aitamurto 2016), where they can survive with false immigration documents and follow informal adaptation paths. This is confirmed by the Russian government's 2015 statistics showing that nearly 3 million foreigners in Russia violated the legal terms of their stays (Pochuev 2015). In fact, some experts estimate that there are around 5 million undocumented migrants in Russia (Chikadze and Brednikova 2012).

Given the magnitude of the shadow economy, the migrant labor market in Russia and the multiple informal and illegal practices revolving around it should not be viewed as abnormal behaviors but rather as institutionalized practices, 
a parallel legal order emerging out of the corruption and weak rule of law that characterizes much of the Russian bureaucracy. Thus, a distinctive feature of the Russian migration regime is the large shadow economy based on its own economy, legal order, and welfare infrastructure (Urinboyev and Polese 2016).

The above considerations have informed my approach in this chapter, which aims to examine not the limitations of the legal system but rather the unintended consequences that empower the agency of migrants to navigate the system. More specifically, in this chapter I aim to show that in hybrid regime contexts such as Russia, migrants are resilient and active agents and creatively use the opportunities provided by the weak rule of law and the corrupt political system to navigate the structural constraints and negotiate and assert their legal status. These processes can be explained by the vested interests of relevant Russian state actors (e.g., the police and immigration officials), where each of these actors view the (informal) migrant labor market as a source of kormushka (a feeding trough) and attempt to "take their own piece" of it. These patterns become particularly discernible when we attend to migrant workers' everyday experiences, tactics, and coping strategies when they attempt to negotiate the "rules of the game" with Russian migration officials and police officers. Although these processes and strategies may come across as manifestation of corruption and a weak rule of law, they actually constitute a real mode of migration governance and, thus, reveal the broader sociolegal context in which migrants' legal adaptations occur. In this chapter, then, I suggest that the study of migrants' legal adaptation should move beyond the structuralist (Western-centric) perspectives that emphasize the importance of one's legal status and the enduring power of the legal environment. That is, in order to better understand migrants' relationships to the host state's law and institutions in hybrid regime contexts, we should introduce a new analytical lens encompassing not only the legal centralistic approaches but also a legally pluralistic perspective accounting for informal norms and practices.

To illustrate these processes, the next sections focus on migrants' everyday encounters with the two aforementioned Russian state actors. As I mentioned earlier, I collected the empirical data presented in this chapter while conducting my ethnographic fieldwork in Moscow between January of 2014 and August of 2018. In the sections that follow, I first present the informal interviews and observations, which focus on migrants' everyday encounters with police officers and immigration officials, two key social arenas through which migrants experience the legal environment in Russia. Throughout what follows, I use pseudonyms for all of the names that appear here. I also present some relevant empirical examples from indepth (semistructured) interviews with 100 Central Asian migrants (Kyrgyz, Tajik, and Uzbek) I conducted between July and August of 2015. The interview questionnaire consisted of 91 open-ended questions and covered 15 different topics. For this specific chapter, however, I chose to present the results specifically focusing on police-migrant interactions. Thus, the chapter focuses on a small portion of 
the empirical data I collected within the larger project. A more comprehensive description of the interview details appears in chapter 1.

\section{MIGRANTS’EVERYDAY ENCOUNTERS WITH POLICE OFFICERS}

In today's Moscow any visitor will quickly notice the large number of police officers visible on all major streets and in all public places. A more attentive observer will notice police officers frequently stopping and checking the identity documents of non-Russian-looking passersby. This is particularly visible on the Moscow metro, where police officers typically stand at the top of the escalator and enthusiastically carry out document checks. Many of these stopped passersby are citizens of Central Asian republics (Kyrgyzstan, Tajikistan, or Uzbekistan) who left their home country given the lack of viable income-earning opportunities.

It is through these street-level massive document checks that the (informal) implementation of Russian immigration policies and laws takes place. In Russia, where the rule of law remains weak and corruption prevails, it is actually police officers who claim the prerogative of defining who is zakonno (legally) residing and working within the territory of the Russian Federation, even though they are not legally entrusted with enforcing immigration laws (Reeves 2013; Dave 2014; Kubal 2016b). ${ }^{1}$ For many police officers, who receive a meager salary from the state, migrants represent the most lucrative source of kormushka (feeding trough), compensating for their low salaries. ${ }^{2}$ As Round and Kuznetsova (2016) observed, when stopped by the police, migrants must show their work patent and labor contract. Police officers understand that the majority of migrants remain undocumented, and even legally employed migrants often experience problems with their residence registration documents since they do not actually live at the address where they are registered. Yet, even if migrants present all of the required documents, police may simply claim that those documents are fakes in order to extort money.

Although these massive document checks by the police clearly contradict Russian legislation, the authorities tacitly endorse them. In Policing Migration in Soviet and Post-Soviet Moscow, Light (2010) explains Russian police's extortionist behavior, referring specifically to the Moscow city government's attempts to keep Central Asian migrants in a constant state of fear and insecurity, thereby discouraging them from settling down permanently in Moscow. This resulted from the Moscow city government viewing migrants as a burden to its budget since migrants use public services without paying for them. Under Russian legislation, however, only the federal government has the authority to regulate immigration. Thus, the Moscow city government and the country's regions do not have the legal right to restrict the entry of foreign nationals. Unable to limit migratory flows, as Light (2010) maintains, the Moscow city government deployed three methods to deter migrants: (a) random checks of migrants' identity documents in public 
places, (b) raids on workplaces (e.g., construction sites) targeting undocumented migrants, and (c) deploying police officers at points of entry and transit areas, such as railway stations and the city's metro system. All three of these methods are implemented by police officers, whose main task is to keep migrants in a constant state of fear and vulnerability so that they do not feel welcome and only seek temporary stays. In return, the Moscow city government tacitly tolerates abusive and corrupt behavior among its police officers.

The system of police performance assessment and reporting serves as another factor driving massive document checks. According to the system of assessment from the Russian Ministry of the Interior, each police officer must disclose a certain number of criminal cases and report them to higher authorities so as to collect the required points and demonstrate that s/he is indeed "working" (Dubova and Kosal's 2013). This assessment method, commonly known as a palochnaya sistema or plan (quota system), was developed during Soviet times and continues to enjoy wide practice in the post-Soviet era as a key method of performance assessment of police officers on a monthly basis. This requirement forces them to invent various schemes and tactics. For instance, each month police officers must disclose a certain number of robbery and prostitution cases. Instead of doing real work, they stop two Uzbek female migrants in the street, bring them to the police station, and ask them to sign a sheet of paper indicating that they were involved in prostitution. Quite often, migrants do not read the paper but sign it so that they are quickly released. After getting their signature, the police let them go. In turn, police officers report to their superiors that they caught two sex workers and fined them. This is how they fulfill the "prostitution quota." The same logic applies to document checks and bribes. On a daily basis police officers stop and check the identity documents of a certain number of migrants in order to generate revenues for their superiors and themselves. But getting caught by police officers is particularly risky during the last part of month, since police officers must catch undocumented migrants and transfer their cases to court. Therefore, migrants commonly use the expression planga tushib qolish (fall within the quota/plan) to apply to migrants whose cases are transferred to court for possible deportation. Aware of these possible risks, many migrants avoid public places at the end of each month.

Given these realities, migrants understand the near impossibility of being "completely legal." As one migrant rights' activist ironically described it, "the primary aim of Russian migration laws is to fight against legal migrants, not illegal migrants."3 As a result, migrants have developed various informal strategies and tactics to navigate the system, a parallel world based on its own rules. Rather than trying to be "legal," an unrealistic and unattainable status in contemporary Moscow, many migrants simply buy fake work permits and residence registration documents produced at underground printing houses at Moscow's Kazansky railway station. Echoing these views, Salim explains why many migrants are reluctant to legalize their work and residence status in Russia: 
It is almost impossible to go legal [qonuniy]. Even if you try to follow all of the laws and have proper documents, melisa [police officers] can always find a way to "milk you" [extort money]. Therefore, instead of paying the patent [work permit] fee each month, it is easier and cheaper to buy fake documents at Kazansky vokzal [railway station]. The rate of the bribe is almost the same, regardless of whether your documents are clean or fake. (Salim, 35, male, Uzbek janitor in Moscow)

In reality, Salim's observations are not unfounded. Many migrants I interviewed stated that if a migrant is caught by the police without any documents, s/he must pay a bribe of 5,000 rubles (US $\$ 80$ ) to be released. But, if a migrant shows at least fake documents to the police officer, the rate of the bribe decreases and s/ he can get away with paying approximately 2,00o to 3,000 rubles (US\$30-\$45). Indeed, when stopping migrants on the street, police officers cannot verify whether migrants have authentic documents. This is because immigration law lies clearly under the prerogative of the General Administration for Migration Issues of the Ministry of Internal Affairs (GUVM). Thus, district-level police officers do not have direct access to the GUVM database and must submit an inquiry to GUVM if they want to determine the authenticity of immigration documents (Kubal 2016b). Many police officers are overburdened with various tasks and uninterested in transferring each migrant's case to the courts. Instead, they endeavor to release migrants as soon as possible after they pay a bribe. This represents an optimal outcome for both parties: the police officer generates additional income, and the migrant continues to work in Russia using fake immigration documents.

To further investigate this, during the last period of my fieldwork in August 2018, I conducted daily observations in Moscow's metro stations, streets, and public areas such as parks, shopping malls, and supermarkets in order to gain insight into how migrants organize their daily lives and routines. Interestingly, wherever I went, whether in metro stations, bus stations, or parks, I observed many instances of police officers checking the documents and bags of several migrants. Through careful observation, it is possible to witness those migrants pulling money from their pockets to bribe the police. I also conducted observations at the Kazansky railway station, a primary migration hub in Moscow where migrants acquire fake and clean fake immigration documents. When leaving the Komsomolskaya metro station, I came across Bakhtiyor, an Uzbek middleman selling registratsiya (a residence registration document). Some passerby migrants approached him, asking about the price of the registration and whether it works when shown to the police. Accordingly, he provided a price list and told them about three different types of registrations. Bakhtiyor explained that they can buy a "handwritten registration" for 300 rubles (US\$5), a "printed registration" for 500 rubles (US\$8), or a "clean fake registration" for 1,500 rubles (US\$25). When the migrants asked him which worked best, Bakhtiyor responded that the "clean fake registration" was the best since it can be found in the official database. Furthermore, Bakhtiyor described 
the other two types - handwritten and printed registrations-as fakes not existing in the official database, which may cause problems if the migrants were caught by immigration officials during raids. He made clear, however, that the printed registration would be sufficient to convince police officers on the street, who often lack the time and energy to check the authenticity of documents. It is noteworthy here that Bakhtiyor honestly informed his potential clients in advance of the pros and cons regarding when and where his products work. This example illustrates that what identifies a document as fake or real is not simply its quality as authentic; contextual and situational factors also matter.

In addition to contextual and situational factors, migrant's individual navigational skills are also important. The case of Hoshim (33, male) and his brother Nodirbek (25, male) provides a relevant example. On April 14, 2015, Hoshim and Nodirbek visited Moscow's Red Square for sightseeing. Hoshim was planning to return to Uzbekistan the next day, so he wanted to do some sightseeing before leaving Moscow. In fact, Hoshim had a fake work permit and residence registration, but his brother Nodirbek had an authentic patent and "clean fake" residence registration that would appear in the database if checked. If these two brothers were stopped and checked, one may quickly assume that Hoshim would experience trouble with the police since his documents were fake, while Nodirbek would be allowed to go free. As anticipated, when exiting the Okhotny Ryad metro station, the police stopped both Hoshim and Nodirbek for a document check, and the two brothers were taken to a small room inside the metro station where the police usually check migrants' documents. Ironically, Nodirbek ended up paying a bribe to the police officer, whereas Hoshim was allowed to go without losing any money. While taking the bribe, the police officer praised Hoshim for going "legal" and warned Nodirbek that he would not forgive him the next time if he was caught with fake documents. The police officer also added that Nodirbek should follow his brother's example and go "legal" in Moscow. When I asked Hoshim to comment on this situation, he replied that his brother was a young, inexperienced migrant and did not know how to behave when stopped by the police. Unlike his brother, Hoshim was street smart and knew how to appear "legal" when talking with the police. Hoshim explained that one's legal status does not entirely depend on the existence of authentic documents. Instead, and more importantly, one must master the street rules and learn how to perform "legality." This anecdotal evidence illustrates the importance of informal rules and street life in migrant legal adaptation processes and reveals the peculiarities of Russia's immigration legal regime, wherein migrant's legal status remains fluid and depends on contextual factors and individual artistic skills.

The case of these two brothers is far from unique. I observed many similar incidents during my fieldwork, where street smartness, knowledge of the informal rules, and bribe-negotiation skills played a decisive role in migrant-police interactions. Aziz's experience with a police officer illustrates this: 
Two weeks ago, my friend Olim and I were returning to our accommodation from work. Suddenly, a police officer popped up in our way and asked both of us to show our documents. My friend Olim had documents (although fake), but I forgot my documents in the apartment. After checking us, the police officer said that Olim can go, but he asked me to follow him to the police station. Olim did not want to leave me alone and tried to negotiate with the police officer. But I immediately stopped Olim and asked him to leave me alone with the police. Because Olim came to Moscow recently, he did not know that police officers were psychologists and their expectation of the bribe rate largely depends on the migrant's behavior. By trying to help me, Olim was actually increasing my value, which in turn results in a higher bribe expectation. In an everyday situation, for example, where the normal bribe rate is 500 to 1,000 rubles (US\$8-\$15), I might have ended up paying 2,000 rubles (US\$30) if Olim continued to negotiate further with the policeman. If your friend walks away and leaves you alone, the police understand that there is no one who will get you out of trouble, so he will release you for 500 rubles. Because I had many similar experiences, I was not afraid of the police, and this time I decided not to pay even a single ruble to him. The police officer locked me up in a temporary cell and offered to release me if I gave him 1,000 rubles. I knew that he would not keep me long, and I told him that he can keep me in the cell forever, if he wanted. As anticipated, the police officer kept me in the cell for three hours and, finally, after seeing that I was determined not to give him any money, he became frustrated and threw me out of the police station, swearing loudly "poshel na khuy churka" [fuck off, dumb ass]. Due to my patience, I was able to save 1,000 rubles. The only bad thing was that I was hungry and could not eat until I was released. (Aziz, 32, male, Uzbek construction worker in Moscow)

Sardor's story is even more intriguing, illustrating migrants' resiliency and resourcefulness. On January 20, 2016, Sardor finished work quite late and missed the last train to his accommodation, situated in a Moscow province district. He only had 200 rubles in his pocket, and it was freezing outside, with an air temperature of around $-18^{\circ} \mathrm{C}$. Thus, he needed to find alternative accommodations urgently. Suddenly, he saw two police officers on a night patrol at the station. Because Sardor needed a place to stay, he started screaming and pretended to be drunk, hoping that the police officers would notice him and then take him to a police station where he could spend the night. As expected, the two police officers quickly approached Sardor, and one of them kicked him in the ass, a method typically applied to show that Central Asian migrants are nobodies in Russia. Sardor needed a place to stay, so he did not react to the police officer's action and obediently followed their orders. When they reached the station, Sardor was placed in a cell where migrants are temporarily kept. But Sardor was aware that the police would not keep him long, so he needed to do something in order to extend his stay in the cell until the morning. Luckily, Sardor had a Huawei tablet with him, which had lots of pornographic movies on it. He quickly began playing one of the finest movies, hoping that the police officers would be interested. This strategy 


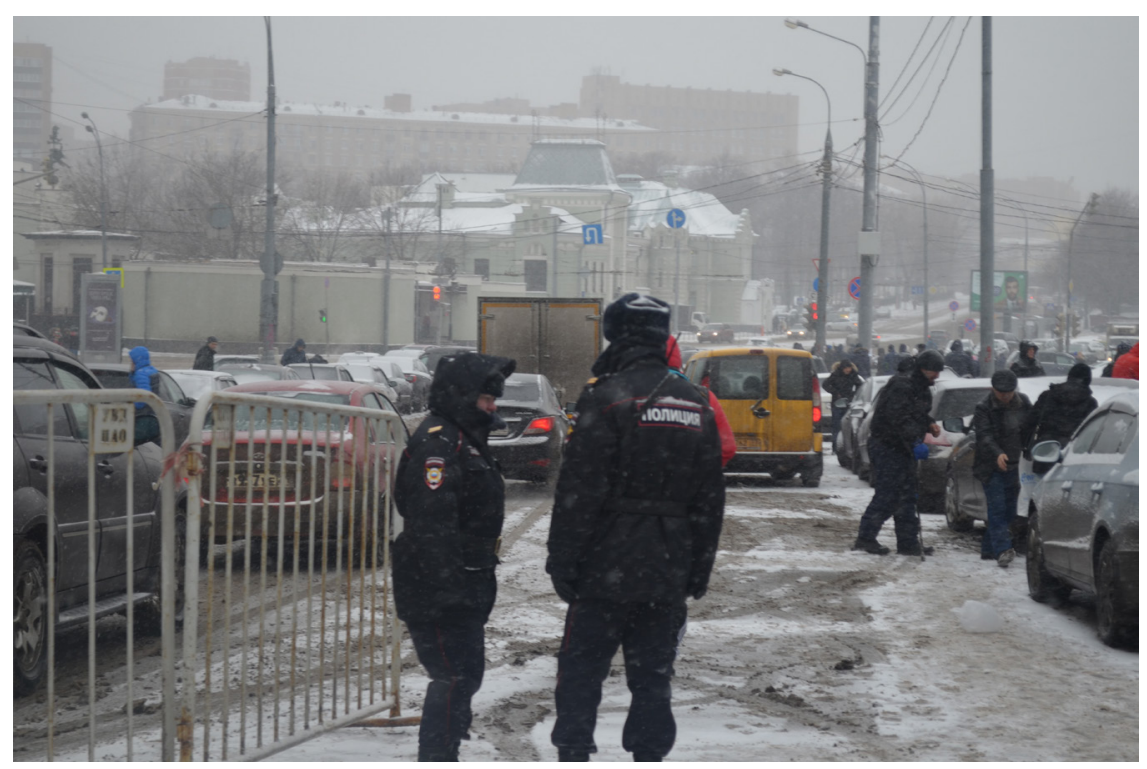

FIGURE 8. Russian police officers work hard and hunt for money (i.e., migrants) during cold winter days. Moscow, January 2015. Photo by author.

worked well and grabbed the police officers' attention, since they were bored with their daily routines and eager to do something fun to kill time. Sardor also had cigarettes with him, and he gave the entire pack to them. Given these strategies, Sardor managed to please the police officers and quickly befriended them. As a result, Sardor was allowed to sleep in the cell until morning.

These examples suggest that Uzbek migrants are not merely passive pawns constrained by a repressive and corrupt legal environment but are resourceful, displaying the capacity to adapt to the situation in their host country. Street smartness, knowledge of the informal rules, and mastering bribery skills remain crucial to migrants' survival. Migrants understand that police officers are more interested in generating additional income from migrants than transferring their cases to court for deportation, as exemplified in the following:

Police officers also have a conscience. For example, you agree to a 500-ruble bribe, but you only have a 1,000-ruble banknote. You give them 1,000 rubles and they return 500 rubles to you. As Russians say, "dogovor dorozhe deneg" [an agreement is more valuable than money]. You can negotiate the bribe rate with the police, just like you negotiate the price of potatoes in a bazaar. You state your offer, he asks you to add a little, and you agree. Police officers are also people, and they have children. They have no interest in transferring our cases to the courts or to the immigration office. If they send our cases to court, they will not make any money. Secondly, it will be extra work for them, like going to the court and so on. It is easier for them to take our 
money and release us. They transfer our cases to court only when they have a special order or "plan" from their boss, which directs them to find a certain number of migrants for deportation on that day. (Soli, 41, male, Uzbek taxi driver in Moscow)

During my fieldwork I also conducted in-depth (semistructured) interviews with 100 Central Asian migrants in Moscow (July-August 2015), asking about their daily experiences with Russian police officers (among 14 other topics). Briefly, the basic characteristics of my informants were as follows: 92 percent were male, given the reality of the gendered constitution of Central Asian migrants (approximately 80 percent of all Central Asian migrants are male). In addition, the majority of the interviewees were young, ranging in age from 21 to 45 years old ( 92 percent), married (62 percent), and had completed upper secondary school or a vocational education (84 percent). In terms of employment they worked in construction (55 percent), at a supermarket (10 percent), as a cleaner and in housing maintenance ( 8 percent), in a warehouse ( 5 percent), as a domestic worker (4 percent), as a taxi driver (4 percent), in a bakery (3 percent), and in other sectors ( 11 percent). Only one-third of the informants ( 31 percent) could easily communicate in the Russian language.

In the next section I present some relevant empirical examples focused on migrant-police interactions. These include (a) relationships between migrant workers and the police, (b) corruption and bribes, and (c) migrants' navigational strategies and informal practices. Police corruption remains widespread: 85 percent of the migrants I interviewed indicated that they had paid a bribe to Russian police officers. The process of negotiating a bribe also seems well-established. Both police officers and migrants actively engage in negotiating the rules of the game. Usually (in 55 percent of my cases), police officers initiate bribery and openly state the amount they want. Then, migrants negotiate and try to lower the amount of the bribe. In almost as many instances, though (45 percent), the police officer does not directly ask for a bribe but drops a hint, saying something like, "What do you think? What shall I do with you?" Then, the migrant is expected to take the initiative and state the amount he or she can pay. But police officers usually increase the amount and demand more money. My interviews showed that police corruption has become a norm within the migrant labor market to the extent that 96 percent of the migrants I interviewed provided the same amount for the average bribe ( 500 to 1,000 rubles).

Of the migrants I interviewed, 76 percent stated that Russian police officers now commonly ask for a bribe in migrants' native languages. One of the Uzbek interviewees explained: "Look, we need money and we came to Russia and we are all trying to learn Russian. The same logic applies to police officers. Migrants are feeding their kids. So, police officers are also trying to learn Uzbek. We all need to learn the languages that feed us."

The majority of my interviewees ( 89 percent) believed that police officers' primary motivation for stopping migrants on the street was not aimed at 
maintaining law and order but to find problems in migrants' documents and subsequently pressure them to pay a bribe. And because it is almost impossible for a migrant to be "fully legal" in the Russian context, more than three-quarters ( 78 percent) said that possessing real, authentic documents is not associated with a significantly lower likelihood of paying a bribe to a police officer. Despite widespread police corruption, however, only 4 percent of the migrants I interviewed referred to corrupt policemen as their primary problem. More crippling were the high work-permit (patent) fees (43 percent) and homesickness (25 percent).

\section{MIGRANTS' EVERYDAY ENCOUNTERS WITH IMMIGRATION OFFICIALS}

In this section I focus on the everyday interactions between Russian immigration officials and migrant workers. When examining these daily interactions, I present empirical examples encompassing two different periods: (1) empirical data covering developments between January of 2014 and April of 2016, when the Federal Migration Service (FMS) was responsible for migration management in Russia and (2) empirical data focusing on the post-FMS or GUVM period (April of 2016 through August of 2018), when FMS was dissolved by Presidential Decree on April 5 , 2016, after which its functions were transferred to the General Administration for Migration Issues (GUVM) of the Russian Ministry of the Interior. The presentation of empirical data reflects this chronological order.

In 2014, during my first year of fieldwork, I conducted observations at several FMS offices in the north of Moscow. On January 24 I visited a local FMS office in Moscow's Bibirevo district. When I approached the FMS office, I found hundreds of Central Asian migrants standing in line to submit their documents for work permits. Despite the freezing temperature, around $-25^{\circ} \mathrm{C}$, all migrants were forced to wait outside, queuing in an area consisting of an iron-bar fenced-in space. The area resembled a shed in which sheep are kept within a tiny enclosure complete with iron-bar fencing. This scene left me with the impression that Russian authorities treat migrants as subpar humans. Since there were hundreds of migrants queuing, I did not wait long and asked the person in charge of the queue to add my name to his registration book. He registered my name and told me to return in three days.

As planned, I returned to the Bibirevo FMS office on January 27 early in the morning. After waiting approximately 45 minutes, I was finally allowed to enter the FMS building, where migrants were submitting their documents and biometric data. Inside the office, and together with migrants, I again waited in a queue among those waiting to speak to an FMS official. When standing in the queue, I saw three migrants approach the FMS official managing the queue and ask him if he could expedite the processing of their work permit application if they "thanked him" properly. The FMS official smiled and positively welcomed this gesture but 
FIGURE 9. Reception facility at an FMS Office in Moscow's Bibirevo district. January 2014. Photo by author.

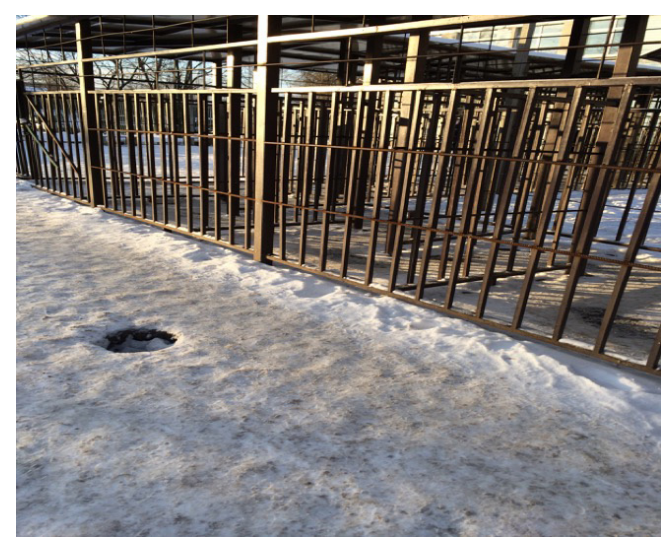

pointed to one Uzbek man standing near the reception area, assuring them that he could fix everything. The three migrants then approached the Uzbek intermediary, asking him if he could help them with their documents. The Uzbek intermediary explained, "If you give me 35,000 rubles (US\$560), I will create a clean work permit for you. I always work halol (honestly), and people who get their documents through me experience no legal problems. As I said, I always work halol." Afterward, he gave the migrants his phone number and instructed them to call him after 6 p.m. Interestingly, this Uzbek man was not an official employee of FMS but rather a posrednik (intermediary) whose main function was to act as a bridge between migrants and FMS officials by facilitating the informal transactions between the two parties. From my observations I concluded that the FMS employee never directly accepted the bribe; instead, they use the posrednik's services to keep themselves free of reproach from corruption charges. That is, the FMS employees used well-organized, institutionalized, and well-established informal practices to accept bribes. Migrants were familiar with this practice and, therefore, primarily used this informal system to obtain work permits.

On April 7, 2014, I visited another FMS office in the north of Moscow. It was a typical workday at FMS, with about 500 to 600 migrants waiting in line. Dozens of buses were situated near the FMS building, bringing many migrants from the Moscow region. I spotted migrants from almost all of the post-Soviet republics, including Armenians, Azerbaijanis, Kyrgyz, Moldovans, Tajik, Ukrainians, and Uzbeks. There were only a few female migrants; approximately 80 percent of all visitors were men. There were no public toilets on the FMS premises. Owing to the large number of migrants, some were pushing the line forward, and the FMS officers screamed and cursed at the migrants to maintain order. The FMS employees did not show any respect toward the migrants and openly used the racial slur churka (dumb ass) toward those migrants who attempted to jump the queue. Since I was viewed as a part of the crowd, I also experienced the "privileges" of being a migrant worker. 


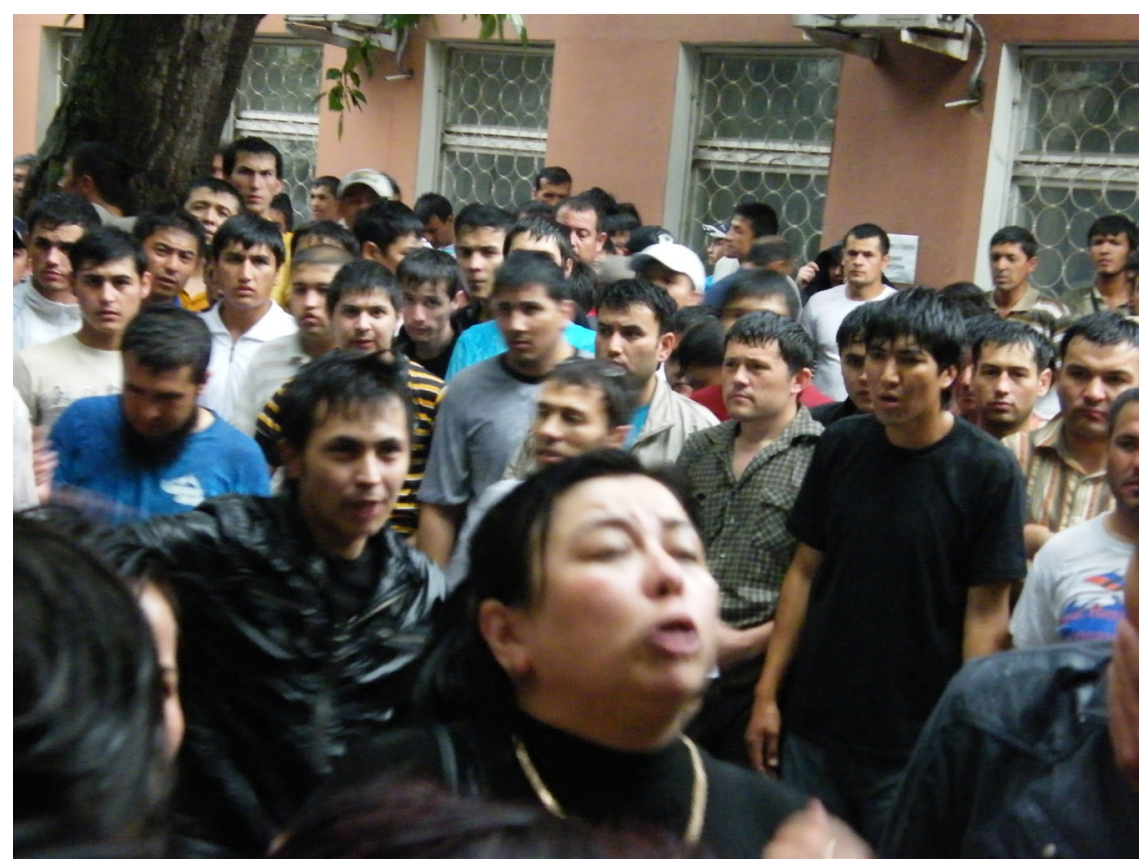

FIGURE 10. Russian Federal Migration Service Office in the north of Moscow. Migrants line up to apply for work permits. Photo by author.

In fact, FMS was blamed for the chaos, since there was no area for those migrants who had to wait, even in freezing temperatures. But FMS created those queues intentionally, because the queues served as a kormushka (feeding trough).

A small "bistro" café situated at the FMS office's gate sold coffee, tea, and snacks to migrants, although the main function of this café was not to sell food and drinks; rather, it served as a place for migrants and middlemen to negotiate the price of two main services: (1) fast-track access to the FMS building for a fee and (2) facilitating a bribe for applying for and receiving a work permit. In truth, this café, owned by Armenian migrants, did not exist the previous year. Before opening the café, the Armenian migrants "settled" in the FMS office by selling coffee, tea, and hotdogs from a car's trunk to migrants submitting their documents for work permits during the cold winter months. In addition to selling drinks and fast food, they also offered the opportunity for migrants to warm themselves up in their car for 500 rubles (US $\$ 8$ ). In addition, they charged 1,000 rubles (US $\$ 15$ ) if a migrant wanted to enter the FMS building ahead of others. Previously, they worked as follows: a migrant arriving at FMS at midnight paid 1,00o rubles. As a rule, if the migrant wanted to enter first, s/he had to register her/his name first. Thus, migrants arrived at midnight, slept in the car until the next morning, and then registered their name first when the FMS employee opened registration. This 
business became quite profitable, and the Armenian migrants became rich, subsequently opening their bistro. Because of their daily presence in the FMS area, the Armenians established a close relationship with the FMS employees, allowing them to create an informal, fee-based fast-track system that they offered to migrants. The standard rate for fast-track access was 2,000 rubles (US\$30). If the line was too long, the price may increase to 3,000 rubles (US\$45). Migrants who did not pay for fast-track access were forced to wait at the FMS premises for many hours, in some cases, up to three days. The profit generated from this informal business was shared equally between the Armenians and the FMS employees. For example, each day they sold about 70 to 80 fast-track access "passes," collecting approximately 150,000 rubles (US $\$ 2,400$ ).

These observations indicate that the bureaucratic process of applying for a work permit was intentionally designed to be complicated, such that migrants would be compelled to approach informal actors (such as the Armenians mentioned above). The harder the process of obtaining a work permit was, the more willing migrants would be to informally pay intermediaries. As one immigration lawyer in Moscow explained, FMS employees are not well-paid; thus, they intentionally extend the document processing times in order to create queues. These queues then generate an additional source of income for them. ${ }^{4}$

Another area where immigration officials and migrants come into daily contact lies in the system of residence registration. In Russia all foreign citizens and stateless persons must register within seven working days after their arrival at the address where they reside. The FMS/GUVM, responsible for immigration control and management, also manages the registration service. But migrants cannot independently register their address. If migrants attempt to register, they must appear with their landlord. But few landlords in Moscow agree to register Central Asian migrants at their address, given fears originating from Soviet times that a person registered at their apartment might obtain co-ownership rights following residence for a certain period of time. Landlords, thus, are also reluctant to legally rent apartments to migrants, since they think that the apartment will turn into a "rubber apartment," a location where a tenant might bring another 20 migrants to the apartment, an illegal practice. Migrants cannot afford to rent apartments alone, given their low salaries. Typically, 15 to 20 migrants share an apartment and the cost of the monthly rent. These constraints create an informal market for residence registrations, whereby intermediaries, typically well-connected with immigration officials, offer a fictitious registration service.

The residence registration rules were further tightened following adoption of a new Federal Law (N 163-FZ), "On Amendments to the Federal Law on the Migration Registration of Foreign Citizens and Stateless Persons in the Russian Federation." Until June of 2018, migrants could register at the legal address of the company employing them. Following legislative changes, however, migrants were no longer allowed to register at the juridical address, meaning that registration was 
possible only at an individual's actual residential address. Clearly, many migrants could not comply with these new rules, which created further demand for the services of informal document intermediaries. The Russian police were also granted an additional opportunity to extort money from migrants since they understand that no migrant actually lives at the address linked to their registration. In other words, the residence registration serves as another source of kormushka for many Russian state actors, as illustrated in the words of one immigration lawyer I interviewed during my fieldwork:

If there was a desire to have more legal migrants, they [the Russian authorities] could easily restore order by eliminating the residence registration requirement. Apparently, many forces do not have such a desire. One of our former deputies sent a proposal to FMS/GUVM suggesting the complete abolishment of the residence registration rules. He justified his proposal by referring to the large number of illegal migrants as well as to the extensive bureaucracy and extra paperwork immigration officials must deal with in their daily work. But, he received a negative response from a high-level immigration official. It is quite obvious that they do not want to abolish the registration system because they generate large revenues from it. ${ }^{5}$

Nasiba's case serves as a relevant example here. On August 5, 2014, I went to an air ticket office situated next to a metro station in northern Moscow. This ticket office was managed by Nasiba, a 40-year-old female migrant from Osh, southern Kyrgyzstan. Officially, she sold air tickets to migrants; in reality, however, her primary job was to act as an intermediary between migrants and immigration officials with regard to residence registration, work permits, and other immigration documents. Profits linked to selling tickets remained quite small, since Nasiba sold tickets quite cheaply without adding to the original ticket price. Instead, she generated most of her revenues from facilitating migrants' immigration documents. Nasiba was fluent in the Russian language and had a solid command of Russian immigration laws.

In addition to immigration documents, Nasiba also provided various types of services. For a fee of 1,000 rubles (US\$15), Nasiba checked whether migrants had any administrative offenses registered in different government databases, possibly leading to the issuance of an entry ban. Given that an individual could receive an entry ban even for minor administrative law violations, many migrants were eager to check whether any offenses might prevent them from reentering Russia. Nasiba also provided information regarding any pending fines applied to migrants, when and where they were issued, and, in cases of an entry ban, when, where, and why it was issued. These types of information were available only through the FMS and border service databases, since they shared a combined database. The database for traffic police was also linked to the FMS database, since traffic code violations were also linked to the entry-ban system.

All of these means of access were possible given Nasiba's connections within the FMS. Since many migrants were not in a position to independently secure 
immigration documents, the role of document intermediaries like Nasiba remained crucial in facilitating migrants' legal adaptations. Nasiba typically took photocopies of migrants' paperwork and sorted various other issues and procedures herself (e.g., completing and submitting applications). When the documents were ready, she sent the migrants to the FMS office and secured fast-track access for them so that they could leave their fingerprints and pick up their documents. When I asked Nasiba whether immigration documents produced at Moscow's Kazansky railways station were reliable, she said that she viewed most documents issued through sources there as fake. As she explained, at Kazansky station they provide nicely designed residence registrations and work permits, but each of these are typically fake and do not appear in the FMS database. Nasiba frequently boasted that the residence registrations and work permits "issued" by her office carried a 100 percent guarantee, thanks to her connections at FMS:

I had a colleague who worked with me here. Currently, she works part-time at FMS. She cooperates with us in exchange for kickbacks. Therefore, all of the registrations we issue are clean since we get them directly from FMS. If I created fake documents, I could not continue to work here, because migrants would come and shoot me. I am just a posrednik; migrants come and submit their passport copies and migration cards. I scan those documents and send them to our contact at FMS. After that, they complete the registration form, stamp it, and send the completed document.

One could argue that the setting up of Multifunction Migration centers in Moscow, Moscow region, and other major cities has made it easier for migrants to acquire legal documents. One of the first and largest multifunctional migration centers was opened in 2015 at Sakharovo, a small village located in the Troitsk administrative district, which lies $64 \mathrm{~km}$ from Moscow city. Unlike in the past, when migrants obtained their work permit documents through intermediaries and waited in long queues, as of 2015 migrants could obtain the required documents and apply for a work permit (patent) independently, without making an informal payment to an intermediary for services and fast-track access. The only disadvantage to this system was that the multifunctional migration center lies quite far from Moscow, meaning migrants must travel long distances and lose one full day of work.

Indeed, when we read the "law in books," the procedures for obtaining immigration documents might seem somewhat simplified. But, in reality, it has become even more difficult to legalize one's migration status. This is due to high legalization fees and bureaucratic uncertainties and inefficiencies that push many migrants into illegality. Another reason is that immigration officials have limited ability to generate informal benefits that were closely connected with the system of queues and work permits. Following the opening of multifunctional migration centers, immigration officials lost a rather substantial portion of their revenues. The only source of kormushka they now have at their disposal lies in the residence 
registration business. An immigration official who previously earned an additional 50,000 to 100,000 rubles (US $\$ 800-\$ 1,600$ ) monthly today must rely on her/his salary, hardly enough to meet her/his living expenses. Since nearly all processes and services are highly digitalized at the multifunctional centers, no intermediaries are needed, and it is impossible for immigration officials to take bribes.

Given these changes, immigration officials now appear to sabotage the changes, making it hard for migrants to obtain work permits and related documents. Many of the migrants I interviewed stated that immigration officials are excessively strict and refuse to accept migrants' applications for various illogical reasons not stipulated in official procedures. They require migrants to present various documents not mentioned in the list of mandatory documents, such as translating passports into Russian. But, when migrants present these additional documents, immigration officials continue to find issues with them. For example, one Uzbek migrant presented a translated version of his birth certificate, in which the original stated that the certificate was issued by the Uzbekistan SSR; accordingly, the translator also used Uzbekistan SSR. But the immigration official did not accept the translated document, arguing that "SSR" must be spelled out. One case involved the refusal of a migrant's application from further processing given the absence of a comma in the application. An immigration lawyer I interviewed provided this explanation of the flip side of these processes:

Immigration officials are simply sabotaging the process. They intentionally make migrants' lives difficult, hoping that they make noise and complain that the multifunctional migration center cannot serve migrants. They want migration services to be returned to individual districts, so that they can again calmly take money. Most likely, such logic explains their actions. Therefore, where corruption existed before, implementing changes would be difficult. ${ }^{6}$

As the empirical material presented in this chapter demonstrates, both police officers and immigration officials are more interested in having more undocumented migrants than managing labor migration in a more rational and formalized way. This stems from the vested interested of Russian police officers and immigration officials, who regard migrants as a source of kormushka, whereby these actors attempt to "take their own piece" from it. The empirical material also shows that migrants remain active agents in these processes since they develop various strategies and tactics to negotiate the "rules of the game" with Russian migration officials and police officers.

The empirical data presented here should not be understood as an attempt to portray corruption, extortions by police, and other informal practices as arbitrary and unregulated. Although these processes and strategies may come across as a 
manifestation of corruption and a weak rule of law, they should also be viewed as an informal yet real mode of migration governance in Russia. Thus, these processes reveal the broader sociolegal context in which migrants' legal adaptations occur. From this perspective migrant legal adaptation processes in the context of a hybrid regime such as Russia should not be understood merely through the legal centralistic lens that emphasizes the importance of one's legal status and immigration laws. Instead, we must also focus on alternative avenues that account for the role of informal rules and practices in migrant legal adaptation processes. Thus, I conclude that the study of migrants' legal adaptation should move beyond legal centralistic perspectives that emphasize the merciless application of immigration laws (e.g., "legal violence," "legal nonexistence," and "deportability"). To better understand migrants' relationships to the host state's laws and institutions in hybrid regime contexts, a new analytical lens encompassing not only the legal centralistic approaches but also the legally pluralistic perspective accounting for informal norms and practices should be adopted. 